\title{
Tony Blairs storhed og fald - og lidt til
}

\section{Ib Faurby}

Tony Blair var Storbritanniens premierminister fra
1997 til 2007 og i sin regeringstid en af de betydeligste europæiske - ja, internationale - politikere, og han spiller stadig en rolle på den globale scene. Derfor griber man hans erindringsbog med store forventninger - og skuffes

Tony Blair: A Journey. Hutchinson, London: 2010, 718 s. ISBN 9780091925550 .

Polonius: "What do you read my Lord?" Hamlet: "Words, words, words". (William Shakespeare, Hamlet)

I introduktionen skriver Blair, at han ikke har ønsket at skrive en traditionel politisk erindringsbog. Den slags bøger er "rather easy to put down". I steder vil han beskrive den rejse gennem en bestemt historisk periode, hvor hans politiske og "maybe to a certain degree my personal character evolves and changes. I begin as one type of leader; I end as another".

Og det er netop det, der er pro- blemet. Der, hvor bogen er mest interessant, beskriver Blair konkrete politiske begivenhedsforløb, som $\mathrm{fx}$ i kapitlet om de komplicerede forhandlinger, der førte op til 'Langfredagsaftalen' (The Good Friday Agreement) om Nordirland. Der, hvor den er værst, er i den selvforherligende retorik, der til tider nærmer sig det kvalmende.

\section{New Labour}

Blairs afgørende betydning i britisk politik var hans succes med under banneret 'New Labour' at modernisere partiet og gøre op med den traditionelle, fagforeningsdominerede ideologi og indflydelse. Han fik fjernet 'Clause Four' i partiets program, 
der talte om statens overtagelse af samfundets produktions-, distributions- og finansieringsmidler.

Ændringen havde måske kun symbolsk betydning, men symboler kan være vigtige i politik. Han fik også gennemført afgørende reformer i sundheds-, uddannelses- og retspolitikken. Blair betegner sin politik som 'den tredje vej' mellem Labours traditionelle holdninger og britisk konservatisme. Efter 18 års ørkenvandring bragte denne politik ikke alene Labour til magten, men partiet genvandt den under Blairs ledelse to gange - en historisk enestående indsats.

Udenrigspolitisk gjorde han op med Margaret Thatchers anti-europæiske politik og gav Storbritannien en mere konstruktiv rolle i EU. Men Blairs og Jacques Chiracs SaintMalo-initiativ nævnes ikke, men strejfes blot indirekte i en enkelt sætning og (måske - igen - indirekte) i 10 linjer om EU's forsvarspolitik.

Nok så væsentligt var det, at Blair var den premierminister, der førte Storbritannien i krig fire gange sidste gang i Irak, hvad der blev hans mest kontroversielle beslutning.

Den mindste, men også mest succesrige militære operation var indsættelsen af britiske specialoperationsstyrker i Sierra Leone i 2000 for at befri britiske soldater taget som gidsler af RUF (Revolutionary United Front). Det var, skriver Blair, "one of the things of which I am most proud".

Det hele begyndte med Kosovo. Blair indrømmer, at han som oppositionsleder ikke havde beskæftiget sig meget med udenrigspolitik, og at krisen i Kosovo blev en brat opvågning til de internationale realiteter. "It also completely changed my own attitude to foreign policy". Der var ikke, så han, nogen nødvendig modsætning mellem en moralsk og en realistisk udenrigspolitik - om nødvendigt en militært baseret udenrigspolitik.

Mest interessant er dog kapitlets korte afsnit om uenigheden mellem Blair og NATOs øverstkommanderende, general Wesley Clark, om, hvad de britiske soldater skulle gøre, da russiske styrker overraskende besatte lufthavnen i Pristina. De endte med - på Blairs ordre uden om NATOs kommandosystem - at forholde sig roligt.

Og det var sikkert godt.

\section{Efter 11. september}

Det er imidlertid skuffende så lidt reelt indhold, der er i omtalen af Storbritanniens og hans egen reaktion på terrorangrebet den 11. september 2001 i betragtning af, hvor skelsættende han finder angrebet.

Også i omtalen af krigen i Afghanistan kunne man have ønsket sig flere detaljer. Der er fx kun 12 linjer om etableringen at ISAF (Den internationale Sikringsstyrke i og om- 


\section{LITTERATUR}

kring Kabul), der i høj grad fandt sted på britisk initiativ og under ledelse af Storbritannien de første tre måneder, men som siden - efter flere udvidelser af mandat og antal soldater - fik den centrale rolle i krigen.

Til gengæld er der flere interessante eftertanker om indsatsen i Afghanistan. Blair indrømmer, at han (og de øvrige vestlige ledere) fuldstændig fejlbedømte problemerne i Afghanistan, det afghanske samfunds karakter og Talebans styrke og evne til at fortsætte kampen mod de internationale styrker. Det er også et af de få steder, hvor der er en (ganske vist diskret) kritik af præsident George Bush og hans politik.

Blair afviser, at krigen mod Irak i hvert fald for Storbritanniens vedkommende - fjernede fokus fra Afghanistan.

Ikke overraskende er Irak-krigen med godt 100 sider et af bogens hovedemner. Blair har tydeligvis et behov for at forklare og forsvare sig. Det skal ikke refereres, men blot nævnes, at han indrømmer (i modsætning til den danske regering), at det for hans vedkommende var Saddam Husseins (ikke-eksisterende) masseødelæggelsesvåben, der begrundede krigen.

I et af de få andre diskrete forbehold over for George Bush' politik, afviser Blair, at Irak-krigen havde sin baggrund i Iraks påståede medansvar for terrorangrebet den 11. september 2001.

\section{Blair, Brown og alle de andre}

Bogen har naturligvis givet anledning til megen presseomtale i Storbritannien. Ikke mindst det stadig mere forbitrede forhold mellem Blair og Gordon Brown, der ikke alene er helliget et helt kapitel, men som gennemsyrer flere af de øvrige kapitler.

Forholdet synes at have udviklet sig fra gensidig respekt og samarbejde til indædt uenighed og magtkamp. Blair understreger flere gange Browns intelligens og økonomiske indsigt, men ifølge Blair var Brown en keynesianer, der ikke forstod den nye tids økonomiske vilkår og problemer. I lyset af Storbritanniens aktuelle økonomiske problemer synes det imidlertid, som om Blair og Brown var fælles om denne manglende forståelse. Men ifølge Blair skulle Brown og hans folk blot have fastholdt 'New Labours' politik, så ville alt have været godt.

Om kapitlet om prinsesse Dianas død og begravelse er det blevet sagt, at Blair blot har gentaget fremstillingen i den prisbelønnede film, 'The Queen'. Det er ikke rigtigt - filmen er bedre!

Andre har hæftet sig ved, at Blair indrømmer, at det politiske pres fik ham til at ty til alkohol som afspændingsmiddel: en G\&T eller whisky før aftensmaden og en halv flaske rødvin til maden. Churchill ville ikke have været imponeret! Men der er flere detaljer fra privatsfæren. 
Trods sit hektiske internationale liv har Blair heldigvis ikke problemer med jetlag. Til gengæld kunne det giver problemer med maven, og det er ikke godt for en mand, der gerne vil have god tid på toilettet om morgenen! Som læser får man således mere at vide, end man har bedt om!

Som dansker kan man imidlertid blive lidt ydmyg ved læsningen. Danske soldater er næunt i et par opremsninger af militære styrker i Irak og Afghanistan, men det er så det. Danmark er ikke nævnt én eneste gang i den britiske premierministers erindringer.

Der optræder heller ikke nogen Rasmussen i den 700 sider lange beretning om Bill, George, Silvio, Angela, Nicolas og alle de andre, der viser sig at have lederegenskaber, der angiveligt tåler sammenligning med forfatterens.

Ib Faurby er cand. scient. pol, tidligere chefkonsulent ved Forsvarsakademiet. Medlem af Udenrigs' redaktionskomité. 